\title{
Vida e poesia na janela
}

\author{
PEDRO MEIRA MONTEIRO
}

\begin{abstract}
"El poeta vive en la riqueza de las experiencias del mundo humano, tal como la encuentra dentro de si mismo y como la percibe fuera de sí, y estos hechos no son, para él, ni datos que utilice para la satisfación de su sistema de necesidades, ni materiales a base de los cuales elabore generalizaciones. El ojo del poeta descansa reflexivamente y en quietud sobre ellos; son para él significantes; estimulan sus sentimientos, unas veces de un modo tenue, otras veces de un modo poderoso, por muy lejos que estos hechos se hallen de su propio interés o por mucho tiempo que baya pasado ya desde que ocurrieron: son parte de su propio yo." (Wilhelm Dilthey. Goethe y la fantasía poética. Trad. W.Roces.)
\end{abstract}

"... ciò che noi conosciamo nelle cose è niente altro che noi stessi."

(Antonio Gramsci. Quaderni del carcere.)

\section{Alumbramento, arrebatamento. "Iluminância".}

URIOSO QUE MÁRIO DE ANDRADE dissesse, da “famosa cadência oratória da frase", que desaparecera em Manuel Bandeira, já num de seus livros. Anos depois, Lêdo Ivo tocaria porventura o coração da poesia do "velho bardo", nela encontrando versos livres. "Falsos versos livres", contudo...

A "falsidade" advém de uma métrica oculta, subordinada a um "código individual", interior. O poeta tradicional, sonetista "admirável", compunha-se com o seresteiro todo lírico. Daí talvez o tom moderno de sua poesia: o soneto era composto "maliciosamente", enquanto a simples cantiga era entoada com singeleza, revelando-se porém inescrutavelmente complexa, porque finamente composta. O que era forma tradicional, adquiria acento próprio, ultrapassando as traves da própria forma. O que era forma livre e aberta cerrava-se numa mensagem única, profunda e pungente.

A forma, enfim, não era tanto o problema. A mensagem era o que importava. Mas é impensável que Manuel Bandeira compusesse sem o rigor construtivo de um poeta maior. Compor seria para ele tão somente um gesto natural? Difícil crer. Por certo que as palavras não vinham ao papel sem antes serem laboradas, ainda que interiormente. Somente assim podemos compreender os inúmeros poe-mas que lhe saíram "ao correr da pena". 
Mas chegou mesmo a negar-se o estatuto de "poeta". Poetas eram os cantadores que ele louvou:

... não sou poeta não;

Que poeta é quem inventa

Em boa improvisação (...) (1)

Talvez o rigor de sua composição não fosse tamanho que abafasse a própria criação. Talvez a disciplina civil da forma, expressa na arquitetura sinuosa dos versos e na cesura contensa das palavras, não lhe parecesse assim tão importante. O "rigor" da composição talvez repousasse em seu próprio interior. Mas se a métrica e a cadência respondiam a qualquer coisa de individual, nem por isso as palavras caíam do céu ou saltavam do chão, como as dos violeiros. Eram trabalhadas. Apenas o rigor se escondia então, oculto sob a liberdade falsa de seus versos. Talvez encontremos os fios que amarram sua poesia tentando mergulhar mais fundo do que a forma permite ver. Lendo com os ouvidos, não só com os olhos. Escutando o texto.

Não se tratará porém de uma experiência mística, ainda que o misticismo caiba bem nesse "impenitente místico ateu", conforme, uma vez mais, Lêdo Ivo. Não se tratará tampouco de um curto-circuito entre duas almas (a de quem lê e a de quem escreveu, a de quem ouve e de quem cantou). As almas, aliás, não se comunicam... A tentativa, neste breve artigo, será a de buscar alguns daqueles fios, para percorrê-los imaginariamente, testando sua tesão e vendo aonde afinal podem levar-nos, a que fonte escondida.

Mas mexer com as palavras do poeta e com seus fios invisíveis é um exercício de crítica. Não é portanto pura revivência. Nem é a experiência absurda do encontro definitivo do outro, quando as almas se confundem e podem comunicar-se absolutamente. Mexer com suas palavras é um ato de interpretação e, assim, é a busca do outro, sendo simultaneamente a angústia de nunca encontrá-lo.

Não se trata tampouco de estabelecer um curto-circuito entre a experiência do escritor e a do leitor. Trata-se bem mais de uma tentativa de reexperienciar, de reviver o sentido da vivência do poeta. Trabalho ingente, difícil, cuja completa solução nem de longe se encontra nestas páginas. Trabalho, aliás, sempre precário, sempre em crise, sempre crítico, porque nunca alcança o que procura. Nem alcançará jamais.

Os alemães, muito engenhosos, cunharam um termo de difícil tradução: Erlebnis. Com a Erlebnis (vida?, vivência?, experiência vivida?), talvez possamos nos aproximar um pouco da poesia de Manuel Bandeira. Mas não 
mais no intuito vão de encontrar toda a fonte do poeta, pretensamente repousada em algum canto oculto de sua alma. A experiência da revivência ganha, se procurarmos o caminho da Erlebnis, o plano do exercício hermenêutico. É um bom caminho. Porque recusa, de toda a maneira, a ilusão do pleno encontro. Recusa o sol absoluto da razão, com o qual se crê iluminar cada esconso da alma e do mundo, descobrindo ao fim o sentido da própria vida. Pois a vida permanece refratária a esta ilusão. Vida, afinal, é a renovação perene dos sentidos, esquivando-se às definições para destacar-se como horizonte fluido e infinito, para onde dirigimos nossa luz, sempre precária, sempre insuficiente.

Assim compreender-se-á, talvez um pouco melhor, o rigor plástico do poeta que compõe, marcando uma cadência interior. Cada detalhe do mundo, aparentemente insignificante ou prosaico, pode ser vivido e experienciado pelo poeta, transformando-se em poesia, para daí ser revivido como experiência, parcial e cheia de novos sentidos, pelo intérprete aturdido que é todo o crítico. Poesia, enfim, como manifestação e expressão da vivência. Como invenção de "metros" subordinados a um código especial, pessoal, diuturnamente forjado na experiência cambiante do poeta que vive. Poesia como iluminação da própria experiência, pela luz interior que é também experiência, vida, dor, alegria, temor e desejo. Tudo muito fugaz. "Iluminância".

\section{Mudando de janela}

Em meados de 1953, o poeta Manuel Bandeira mudava-se do apartamento 409 do Edifício São Miguel, na avenida Beira Mar, no Rio de Janeiro, para um apartamento pouco mais alto, localizado no oitavo andar do mesmo prédio. "A mudança foi um verdadeiro terremoto, por causa dos livros", diria a seu confrade Sergio Buarque de Holanda, numa carta datada de 11 de julho, enviada a Roma.

Em novembro, uma segunda carta confirmava a mudança e afiançava a graça da nova morada:

Agora estou no apartamento 806, com vista maravilhosa para a Av. Beira Mar, o aeroporto, a entrada da barra e outras belezas. Por tudo isso resolvi passar a me chamar Lindomar Boavista. Perdi a proteção da lei do inquilinato e pela área do velho apartamento, cujo aluguel era de $650 \mathrm{cruzei-}$ ros, pago agora 3.000! Mas vale a pena: tenho lua, tenho sol e não tenho os ruidos e a fedentina do pátio. Já celebrei o acontecimento num poema. Breve você o lerá numa daquela edição aumentada de Opus 10 (2). 
Entretanto, o poema celebrando o fato fora já enviado àquele destinatário, numa versão um pouco diversa da que sairia em Opus 10. Bandeira aparentemente se esqueceu de que já o havia remetido, quatro meses antes. Talvez se esquecesse da remessa porque não costumava receber com freqüência respostas epistolares do amigo: "cozinhado em água fria de saudade", padecia a falta de "Sergio, compadre ingrato e apesar disso querido", famoso por demorar a responder as cartas que lhe enviavam.

Em meio ao humor engraçado (3) das cartas de Bandeira, reponta algo corriqueiro como uma mudança de apartamento, ocorrência quase banal, já que nem mesmo de prédio ele se mudara. É interessante, porém, que um simples aviso de alteração de endereço pudesse valer mais que a informação propriamente dita, resultando num poema. Não que o prosaísmo do fato fosse "vencido" ou "ultrapassado" pelo gênio poético. Na verdade, a prosaica mudança, com seus incômodos e tormentos, podia ela mesma resultar em matéria poética. O "terremoto" de livros, afinal, fazia-se acompanhar da inevitável mudança de janela e, com ela, uma vista diferente se descortinava. Vista boa para o mar lindo, onde nascia uma lua nova:

Lua Nova

Meu novo quarto

Virado para o nascente:

Meu quarto, de novo a cavaleiro da entrada da barra.

Depois de dez anos de pátio

Volto a tomar conbecimento da aurora.

Volto a banhar meus olhos no mênstruo incruento das madrugadas.

Todas as manhãs o aeroporto em frente me dá lições de partir.

Hei de aprender com ele

A partir de uma vez

- Sem medo,

Sem remorso,

Sem saudade.

Não pensem que estou aguardando a lua cheia

- Esse sol da demência

Vaga e noctâmbula.

O que eu mais quero,

$O$ de que preciso

É de lua nova. 


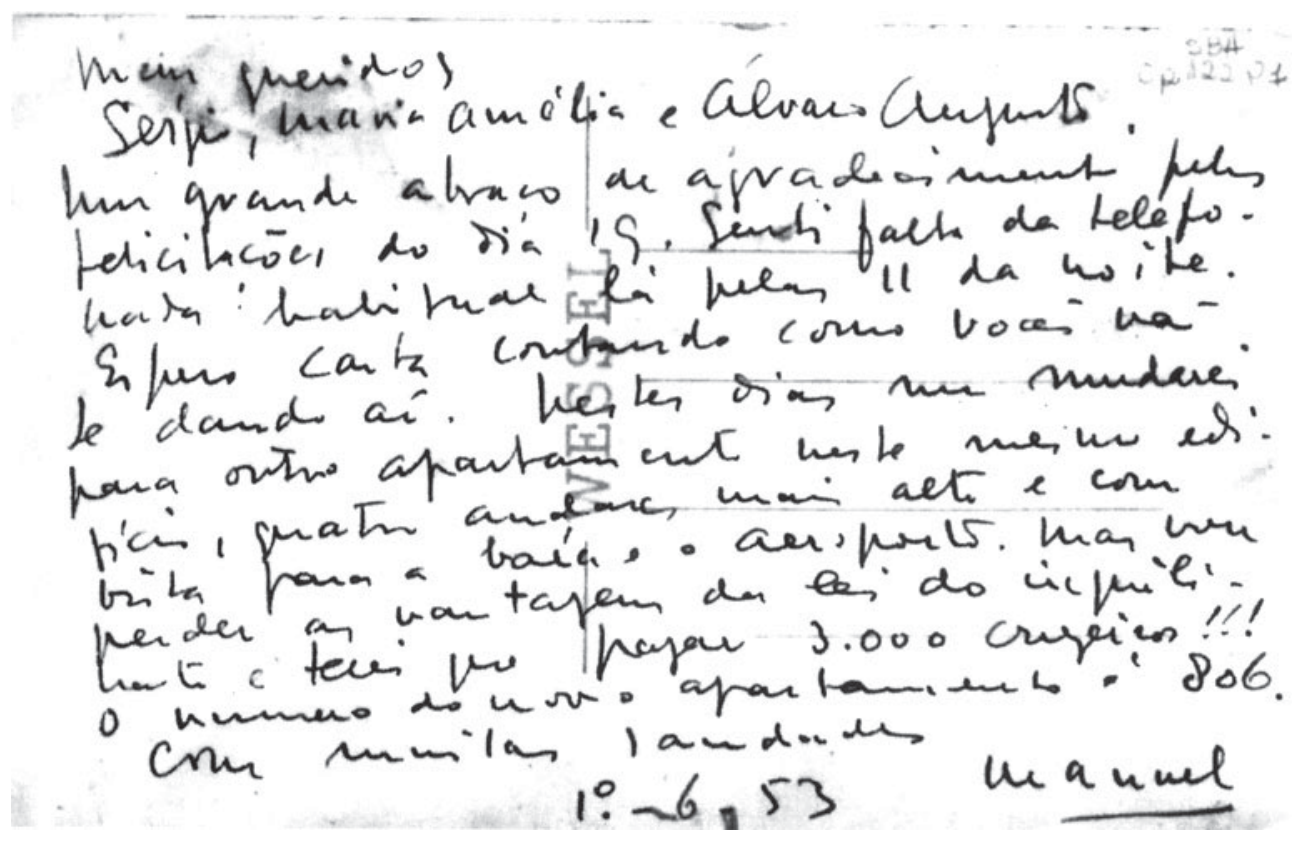

Cartão de Manuel Bandeira enviado a Sergio Buarque de Holanda, em 1953, anunciando a mudança de apartamento. Diz: "Meus queridos Sérgio, Maria Amélia e Álvaro Augusto. Um grande abraço de agradecimento pelas felicitações do dia 19. Senti falta da telefonada habitual lá pelas 11 da noite. Espero carta contando como vocês vão se dando aí. Nestes dias me mudarei para outro apartamento neste mesmo edifício, quatro andares mais alto e com vista para a baía e o aeroporto. Mas vou perder as vantagens da lei do inquilinato e terei que pagar 3.000 cruzeiros!!! O número do novo apartamento é 806. Com muitas sudades $1^{\circ}$.6.53 Manuel".

O pátio ficava agora mais abaixo e o poeta, ao ascender, livrava-se de seus ruídos e de sua fedentina, conforme a carta enviada a Sergio Buarque de Holanda. Mas mesmo o barulho e o fedor abaixo de si já haviam se tornado poesia, pelo exercício infatigável e ascético de sua pena. O ruído de um simples guincho de sagüim ("Minha vizinha de baixo comprou um sagüim") havia já, em certa ocasião, cortado o "sussurro sinfônico da vida civil", num "Comentário Musical” para lá de moderno, que tivera a casa da rua do Curvelo como inspiração. O fedor aparecera, horrível, quase adentrando nossas narinas, no poema que denuncia atônito a barbárie do bicho-homem, mais bicho que homem, a catar detritos naquele pátio do edifício do poeta. Pátio que, ao lado de coisas tão mundanas como o banheiro ou o cambrone, podia ser "núcleo de poesia", segundo outro poema ainda.

Se Manuel Bandeira, como parece, "desentranhava" do mundo a poesia, seria contudo ocioso procurar descobrir o elemento poético no próprio mundo, como se ele estivesse ali, apresentando-se a quem quisesse vê-lo, ou 
talvez oculto sob a capa das aparências, pulsando como um noumeno, inatingível, incognoscível e portanto indescritível, cabendo ao poeta tão somente aproximar-se dele, por meio de sua linguagem fluida, toda metáforas e delírios. Como se o pátio guardasse ele mesmo a poesia. Como se o macaquinho, a latrina ou o homem se constituíssem, por si sós, em poesia.

O elemento poético, se é possível falar assim, não repousa no mundo, mas apenas no mundo tornado significativo pelo poeta. Portanto, no mundo que ele quer apreender, isto é, no seu próprio mundo, iluminado e compreendido por ele. Não haverá mesmo outro mundo, porque este é o mundo da história, sua e do próprio mundo. Nada há exterior a ele, porque todas as suas coisas (o pátio, a janela, o mar, a lua...) somente fazem sentido quando englobadas no horizonte absolutamente pessoal do poeta. Ali sim qualquer coisa pode tornar-se poesia, bastando que lhe diga algo, isto é, bastando que lhe forneça matéria para a composição de uma melodia toda própria, que respeite uma cadência interior, produzindo sons marcados pelo ritmo irregular e fluido da própria vida. Vida do poeta, uma vez mais. Vida que contempla o seu quarto, bem como a simples janela de onde ele descortinava uma nova vista, sempre nova, já que por ali podia ver e ouvir o mundo, experimentando-o e provando-o como novidade que se oferecia, graciosa e gratuita, a cada manhã.

\section{Vida e poesia}

Curioso que os sons possam mexer conosco. Curioso que mexam com o corpo. Nem tanto como vibração do ar, mas como vibração do próprio corpo, a poesia nos põe verdadeiramente a bailar. É que às vezes nos vemos diante de palavras que nos fazem vibrar, porque geram uma agonia ou uma revolta interna que não se pode conter (4). As próprias palavras parecem então incontidas, porque recusam o espaço limitado e a absoluta falta de movimento a que foram condenadas, quando despejadas no papel. No momento da leitura da poesia, as palavras recuperam o movimento e a vibração original, que um dia lhes emprestou o poeta.

Fazem-nos vibrar, porque ressoam em nós. Som e sentido então se compõem, porque o ouvido foi emprestado às palavras. Sem ouvido, haveria apenas som, sem sentido. Manchas no papel, nada mais. Apenas vibração do ar. Onda sonora, apenas. Mas há mais que isso. O corpo se põe a dançar e os órgãos a pulsar, quase autônomos, porque a poesia pode angustiar, como pode fazer cantar.

Há outros momentos, porém, em que quedamos amortecidos e silenciosos diante de uma cena evocada pela poesia. É quando o silêncio se im- 
põe e permanece, sustendo o tempo da vibração, mas mantendo-se, como silêncio, repleto de sentido, ainda que não seja som. Isto é, mais que cheio de sentido, o silêncio estará porventura grávido de movimento. Ainda como silêncio, ele será o próprio sentido iminente e ainda não revelado. Porque no silêncio, o sentido foi tão somente suspenso, para que pudesse reaparecer logo após, no momento em que renasce o som, reforçado e renovado pela experiência da ausência absoluta. Desde sempre, a ausência absoluta nada mais faz que aprofundar o sentido (5).

Movimento, som, vibração do corpo... Sejam os termos imprecisos, ou pouco dados a análises rigorosas, são contudo absolutamente reais. $\mathrm{Ou}$ haverá quem não tenha vivido a experiência de se sentir mexido pelas palavras? De pôr-se em marcha depois do grito, do som que ordena, imperioso? Haverá quem, por mais contido seja, não tenha experimentado os delíquios e a delícia das palavras de amor, sussurradas ao ouvido?

São termos imprecisos, talvez tão imprecisos como a noção mesma de "vida". Ainda que procurássemos resgatar a riqueza semântica da Erlebnis, não encontraríamos, talvez, muito mais que a afirmação, igualmente imprecisa, de ser Erlebnis a experiência vivida. Ou a vida efetivamente vivida, acontecida. Em todo o caso, seríamos obrigados então a perceber que, ainda nos parecendo imprecisos os termos e as noções, eles nos falam de experiências comuns a todos nós (6). Pois quem não vive efetivamente? Quem não experimenta, ou não experiencia? Até mesmo o verbo experienciar seria então chamado à vida, embora não repouse no dicionário, como sóem fazer as palavras autorizadas.

Pois a vida como valor é o que resta de comum a todos os homens. É o que permite que se viva, se experiencie e se compreenda a experiência do outro. Sendo ainda outro, posso compreendê-lo e reconhecê-lo, porque ele se faz ação e vida, revelando-se-me em sua efetiva vivência. Posso mesmo reviver a sua experiência, ainda que nunca vá abarcá-la toda, sempre a tomando como experiência que eu revivo segundo minha própria experiência, meus valores, meu ritmo, meus sons e meu corpo.

Coloquemo-nos no plano da hermenêutica. Não há nada que se possa compreender sem viver. Mesmo o mais remoto ser humano, o mais estranho, que se coloque no limite do que eu poderia chamar de humano (um homem que cata detritos num pátio, por exemplo), mesmo ele posso compreender, porque sou capaz de reviver a sua experiência, sou capaz de me condoer, de acompanhá-lo, captando parcialmente o sentido ou o abominável sem sentido de sua vida. 
O horizonte é sempre o da compreensão, da revivência que não é experiência vicária, mas re-vivência, vivência nova e renovada pela minha experiência, re-sentida em meu íntimo, num cruzamento de linhas que são na verdade a própria vida, ou cada uma das vivências que a compõem. Vivências minhas e do homem que eu vejo, do homem que eu canto ou do próprio homem que cantou. O papel pode até mesmo ser a superfície onde se gravam essas linhas invisíveis. Mas o papel é apenas matéria estranha, que eu não compreendo.

Eu só compreendo aquilo que vibra em mim. Não haverá nisso misticismo algum. Não se trata de uma vibração transcendente, absoluta, emanada da natureza ou de Deus. É a minha vibração, do meu corpo, que responde, sempre antes da mente, às palavras que me assombram e iluminam. Reencontro então o cosmos, mas como horizonte humano e histórico. Como terra dos homens, de quem não se pode fugir. Nem mesmo com a morte.

A finitude da existência me encarcera neste mundo, entre a vida e a morte, entre céu e inferno, onde tudo parecerá saudade de um tempo que já foi ou será. Pois eu só compreendo o mundo porque ele foi ou é experiência, que eu revivo em mim, porque eu mesmo já vivi, podendo então compreender. Encontramo-nos assim em eterna nostalgia:

(...) En todo lo que me rodea revivo lo que he experimentado antes. Contemplo en el crepúsculo una ciudad callada que se extiende a mis pies; las luces que veo encenderse una tras otra en las casas son para mi la expresión de una existencia pacifica y segura. Este contenido de vida que hay em mi própio yo, en mis estados de espiritu, en los hombres y las cosas que me rodean, forma el "valor de vida" de los mismos, a diferencia de los valores útiles que sus efectos les asignan. Y esto y no otra cosa es lo que nos hace ver primordialmente la poesía. Su objecto no es la realidad tal como se da para el espiritu ocupado en conocerla, sino la indole de mi yo y de las cosas, que se manifiesta en los nexos vitales. Partiendo de aqui se explica lo que nos hace ver una poesía lírica o una narración y lo que no existe para ellas. Pero los valores vitales se relacionan entre sí como corresponde a la conexión de la vida misma, y estas relaciones infunden su significado a las personas, a las cosas, a las situaciones y a los acontecimientos. Por eso el poeta busca lo significante. Cuando el recuerdo, la experiencia de la vida y su contenido de pensamiento elevan al plano do lo típico esta trabazón de vida, valor y significado, cuando lo que acaece se convierte asi en expoente y simbolo de algo universal y los fines y los bienes se traducen en ideales, en este contenido universal de la poesía no se expressa ya un conocimiento de la realidad, sino la experiencia más viva del nexo de la trama de la existencia como sentido de la vida. Fuera de esto, no existe ninguna idea de una obra poética, ningún valor estético que pueda realizar la poesía.(7). 
Impossível interromper Dilthey. A citação se impõe, mesmo longa. A poesia não é retrato da realidade, nem simples imitação. Não é sequer expressão de uma só vida. O poema nasce na trama da existência, no cruzamento dos sentidos, onde a experiência alimenta cotidianamente a vida, fornecendo-lhe valores, os quais se criam, se transmitem e se transformam ao longo das vidas passadas e alheias, tanto quanto ao longo de nossa própria vida. Transformam-se e transmitem-se ao longo da história, seria melhor dizer.

A história se faz na vivência e com os valores, de que são portadores todos os homens. Portanto, todos podem compreender a poesia, quanto mais ela for capaz de se entranhar em suas vidas, na trama pessoal de cada um. Somente minha trama pessoal, porém, pode enlaçar-me à trama coletiva, trama dos homens na sua história. Não há um fio único que eu possa lançar sobre o mundo, para compreendê-lo. Devo entendê-lo, e apenas posso entendê-lo, se lançar toda a malha de minha existência por sobre as coisas e os homens. Haverá então vários fios, várias vivências, que outros, além de mim mesmo, saberão reconhecer, recriando, numa nova "travação de vida, valor e significado", momentos novos de experiência, repletos de sentido.

Faz-se mais clara, então, a possibilidade de desentranhar a poesia de tudo o que for vivência. Não apenas o espetáculo do crepúsculo, que eu reconheço e me traz aquela "paz interior", mas também qualquer detalhe do mundo pode revelar-se como poesia. Qualquer som. Qualquer cloc, cloc, cloc... Qualquer grilinho de voz estridente, troppo amarga. Qualquer sino. Qualquer sapo - em especial os sapos! Tudo é matéria poética, a compor-se em ritmo e melodia:

La peculiaridad del poeta se impone ya cuando la percepción construye formas en el espacio a base de sensaciones simultaneas o ritmos, melodias, formas musicales, de su succesión en el tiempo; en él actuan con una fuerza originaria sobre la formación de las percepciones sus intereses vitales, sus estados de ánimo, sus pasiones (8).

$\mathrm{O}$ mundo entra no universo da poesia, à base de uma musicalidade que fornece mais que a melodia solta no espaço, porque são sons que emanam de uma vivência determinada, de estados de ânimo e interesses vitais capazes de dar significação ao mundo, de fazer com que o poeta o cante. Em tudo o que se coloca como matéria poética, eu posso reconhecer a face e a voz daquele que vive, mais até que a face ou o som das coisas. Na aurora, nos aviões, na lua... não vejo senão o poeta.

Porém, tão-somente o verei? Como poderia compreendê-lo, senão com a entrega de mim mesmo ao texto? Mas entregar-me ao texto é, uma 
vez mais, mobilizar a trama de minha própria existência. Reviver, imaginariamente, com os ouvidos, os olhos, o nariz, a boca, o corpo todo, a imagem que se me revela, buscando aquele "conteúdo universal da poesia" a que se refere Dilthey, para encontrar um sentido que será então simultaneamente meu e do poeta, num encontro de ritmos e de melodias diversas. É porém inquietante, pois o caminho da crítica, assim esboçado, parece excessivamente subjetivo, ainda que se busque o universal da poesia. Mas... e haveria outro caminho?

\section{Quando o particular \\ se torna universal e o universal particular}

A vida, portanto, apresenta-se a quem se dispuser a enfrentar o poema como expressão daqueles nexos. Uma nota do editor mexicano Eugenio Ímaz esclarece, contudo, que os nexos vitais (Lebensbezüge) significam uma espécie de intencionalidade profunda, estampada na "urdimbre de la vida". Dilthey aclara, por seu turno, o papel da linguagem poética: ela não pretende apenas ser expressão ou representação da vida; é aos seus nexos que está referida. A poesia, criadora e renovadora, ganha na verdade o espaço da fantasia e da imaginação, pretendendo alcançar a compreensão da vida, mais que sua simples representação:

... toda auténtica obra poética destaca en el corte de realidad que representa una cualidad de la vida que antes nunca se habia visto de este modo. Al mismo tiempo que pone de relieve una conexión causal de processos o de actos, hace que se revivan los valores que, dentro de la trabazón de la vida, corresponden a un acaecimiento y a las diferentes partes que lo formam. (...) El genio artístico de los más grandes poetas consiste precisamente en presentar el acaecimiento de tal modo que resplandezca en él la trabazón misma de la vida y su sentido. De este modo, la poesía nos abre la comprensión de la vida. Con los ojos de los grandes poetas percibimos el valor y la conexión de las cosas humanas (9).

Mais que relato de algo, a poesia desponta como manifestação dos nexos que se estabelecem pelas vivências dos homens, revelando suas mais profundas intenções. Mas tratam-se sempre das vivências particulares, únicas, que eu posso compreender e amarrar numa nova rede de vivências, desdobrando seus nexos, revivendo-os em busca de novos sentidos.

O ensaio crítico, ainda tímido, me faz então descobrir que a aventura crítica não precisa ser ensaiada apenas por quem detém os códigos da crítica. Porque a própria crítica é experiência acessível a todos. No fundo, a "travação de vida" nos enreda a todos e, portanto, a entrada no poema é facultada a quem se sentir tocado por ele, enlaçado em sua rede de sentidos. A qual- 
quer um capaz de sentir-se vibrar com a poesia. O filólogo talvez seja todo aquele capaz de realizar uma leitura viva. Capaz de "ouvir o sangue", expressão mesma de uma "filologia ativa" (10).

Dilthey associava à memória o conteúdo universal da poesia. A comunhão de sentidos, quando eu sobreponho minha vida à do poeta, ou compreendo suas vivências mediante minhas próprias vivências, se dá na evocação do tempo passado, tornando a experiência expressa no poema acessível, aberta para a compreensão, que não é apenas o ato de entendê-la, menos ainda de explicá-la, mas sim de revivê-la. Daí as metáforas do corpo e do sangue serem tão fecundas.

Manuel Bandeira parte do mais particular dos espaços, o quarto:

\section{Meu novo quarto}

\section{Virado para o nascente (...)}

Tópico comum de sua poesia, o quarto pode representar o próprio passado, abrangendo nada menos que toda a sua história de vida. Em $O$ martelo, na Lira dos cinqüent'anos, "O meu quarto resume o passado em todas as casas que habitei." Em meio ao cotidiano, a certeza da renovação e do dia vindouro advinha da própria constância dos acontecimentos, que, naquele poema, afirmava-se simbolicamente pelo "cântico de certezas" do martelo do ferreiro, soante todas as manhãs. O poeta sentia-se então protegido, fosse ainda na "noite", no "cerne duro da cidade".

Mas em Lua Nova parece haver, logo de início, uma inflexão nesse "cântico de certezas". É agora "um novo quarto / Virado para o nascente". Novo, porque resultado da experiência da mudança, do "terremoto" que o poeta tão graciosamente relatara ao amigo distante. A simples vivência da mudança se estampa então na novidade anunciada logo no intróito da estrofe, nos dois primeiros versos, em que se marca um tempo de renovação. Capta-se então a atenção do leitor mediante a anunciação, reforçada pelos dois pontos, que parecem pedir-lhe que aguarde as novidades, porque elas virão. Os dois pontos, sinal de decorrência, são na verdade a própria anunciação, marcando o tempo que virá, renovado:

\section{Meu novo quarto}

\section{Virado para o nascente:}

O leitor pode então esperar aquilo que se anuncia: a completa novidade, expressa já no título do poema, "Lua Nova”, símbolo eterno de renovação, como aliás o próprio "nascente" para onde se volta o novo quarto. Mas 
o poema segue linhas sinuosas, travadas em sentidos diversos, retesadas por forças que vêm do futuro anunciado e esperado, mas também do passado acolhedor e sereno, que o poeta aparentemente abandonara, mas que logo no verso seguinte vemos retornar, num movimento circular, com o registro familiar quebrando a expectativa da novidade:

\section{Meu novo quarto}

Virado para o nascente:

Meu quarto, de novo a cavaleiro da entrada da barra.

Impressionante o ritmo, a cadência dos versos. (Faça-se jus a Mário de Andrade: ele dizia da "famosa cadência oratória da frase", e aqui, de fato, não é a cadência oratória tradicional que se ouve, senão uma cadência toda interior, o que reforça, de qualquer forma, a impressão de Lêdo Ivo.) "Meu novo quarto", "Meu quarto, de novo", são palavras que nascem num ritmo tal que se é conduzido a um movimento imaginário de eterno retorno (11). Imaginário, mas ainda assim movimento do corpo, que se sente impelido, sem sequer a interferência da razão, a balançar com o ritmo dos versos, a dançar com o poeta, com os tempos diversos que ele evoca. Movimento semântico e sonoro se irmanam. Novamente:

\section{Meu novo quarto}

\section{Virado para o nascente:}

Meu quarto, de novo a cavaleiro da entrada da barra.

Os versos me embalam na cadeira, se leio sentado. Bailo sozinho, balançando em torno de mim mesmo, se estou em pé. É impossível parar a poesia, impossível parar o movimento do corpo, acionado pelos vocábulos. Há no fluxo regrado mas quase transbordante das palavras do poeta qualquer coisa que lembra os fluxos internos do corpo, ou mais precisamente o sangue referido por Nietzsche. Impossível ler Lua Nova como um "ocioso". Seria de fato odioso.

O que era expectativa no momento dos dois pontos, quando se respira buscando represar o ar necessário para o advento da anunciação, converte-se, num ritmo de eterno retorno, em evocação do passado. Como se repentinamente nos lembrássemos que mesmo a graça da natureza - a "lua nova" não é mais que uma meia novidade, um ponto qualquer de um ciclo que não tem fim.

Não é mais o futuro incerto que se evoca, mas apenas o passado familiar, como se as casas já habitadas pelo poeta se intrometessem no poema, 
quebrando qualquer expectativa de pura novidade: "Men quarto, de novo a cavaleiro da entrada da barra”. O registro é familiar, não apenas porque o quarto está ainda no mesmo prédio, embora mais alto, mas também porque um leitor de Bandeira reconhecerá o tópico. Em Libertinagem, no Comentário musical que referi antes, encontrava-se já "O meu quarto de dormir a cavaleiro da entrada da barra". De qualquer modo, o "de novo" expressa o movimento circular, o ritornello que pode ligar os apartamentos no Edifício São Miguel à rua Morais e Vale, à rua do Curvelo, à rua do Triunfo, à rua Goulart, à rua Nossa Senhora de Copacabana, aos quartos do sanatório em Clavadel, à rua Senador Furtado, à travessa Piauí ou à antiga rua da Ventura, onde nasceu o poeta...

Mas o tempo passado continua fluindo, paradoxalmente, no poema. Em seguida à primeira estrofe, o registro familiar retorna, com o tempo dos "dez anos de pátio". Na versão original, enviada ao amigo em Roma, houvera na verdade "vinte e três anos de beco e de pátio", numa referência um pouco mais dilatada em relação ao passado, incluindo os tempos dos becos da Lapa, quando Manuel Bandeira morava na rua Morais e Vale. Tempos do Beco a que ele dedicou uma derradeira canção, belíssima, tristíssima, em 1942 , bem antes que demolissem a pobre casa que o abrigara. É como se aquela Última canção do beco, publicada na Lira dos cinqüent'anos, selasse uma fase, repleta de tristezas, perplexidades e "paixões sem amanhã". Isto porque, no labor com as palavras, o poeta resolveu mesmo ficar unicamente com os "dez anos de pátio":

\section{Depois de dez anos de pátio}

\section{Volto a tomar conhecimento da aurora.}

Parece que os 13 anos de "Beco" já foram cantados. Os "dez anos de pátio" prevaleceram, bastantes, configurando-se em paisagem familiar, significativa, como a matéria poética que Bandeira retirava de uma vivência familiar. Foram tempos literalmente sombrosos aqueles, de um pátio imundo em que os homens se pareciam com os bichos. Tempos de fedentina e sujeira, segundo a notação jocosa daquela carta de novembro de 1953. Tempos sombrios que, postos ao lado da "aurora", ganham tons especialmente lúgubres.

Há por certo um efeito de claro-escuro no conjunto desses dois versos: da treva à luz que nasce; do pátio à desejada aurora. A impressão passa a ser então a de algo luminoso que se revela, como que vindo de um fundo sombrio. Uma figura que se destaca e nasce no conjunto enegrecido, causando a sensação de aclaramento, esclarecimento, quando as nuanças se 
tornam perceptíveis, porque jogadas num mundo que é simultaneamente luz e sombra. Uma verdadeira ascese em que se eleva também o leitor, alçando-se do ambiente mundano do pátio à clareza esquecida da aurora.

O segundo terceto guarda em si um movimento peculiar, mantendo porém a ordem circular já anunciada antes. O que é novidade e luz irrompe na ascese, mas dá a ver algo que já era conhecido do poeta:

Depois de dez anos de pátio

Volto a tomar conbecimento da aurora.

Volto a banhar meus olhos no mênstruo incruento das madrugadas.

Mais um movimento de retorno, de re-conhecimento, de re-encontro do que foi perdido ou esquecido. A paisagem se recompõe, mas tornase familiar, talvez ainda mais familiar do que fora antes, porque aqui é o tempo renovado que se abre como ponta de esperança, estampada na Volta. Movimento semântico e sonoro atuam novamente juntos. Como na estrofe anterior, há uma pausa ao fim do segundo verso. Lá, porém, eram os dois pontos que anunciavam. Aqui, é o ponto final que apenas guarda o momento da retomada, reforçada anaforicamente pelo duplo "volto..." e pelo movimento ondulante que é o do terceto. Novamente bailo, novamente pulso... Impossível parar, impossível recusar o movimento que nos toma e nos leva, aparentemente na deriva das ondas, mas de fato na música minudentemente calculada do poeta. Cálculo, claro, que se faz a expensas de um mundo que não é só de luz, mas está repleto de sombras.

Nessa segunda estrofe, contudo, o movimento é ligeiramente diverso, porque não se encerra no círculo. A rigor, a abertura e o fechamento, se assim é possível dizer, funcionam de formas diferentes nos dois tercetos. No primeiro deles, há antes o abrir-se ("Meu novo quarto / Virado para o nascente:") e depois o fechar-se ("Meu quarto, de novo a cavaleiro..."). O jogo, também anafórico, do "novo" e do "de novo", conforma o quadro pulsante do abrir e fechar, a que se entrega todo o leitor não-ocioso. Já no segundo terceto, parte-se do universo fechado ("Depois de dez anos de pátio") para a abertura luminosa que fora antes anunciada ("Volto a tomar conbecimento da aurora. / Volto a banhar meus olhos...”). O pulsar é o mesmo, mas visto e vivido em momentos diferentes. Aliás, o pulsar apenas se deixa compreender e sentir (reviver...) se tomados e lidos os seis versos juntos, os dois tercetos com sua única onda.

Um jogo matemático se oculta sob as palavras, mas revela-se à análise, desde que o analista se disponha a pulsar com o texto, a movimentar-se, a 
dançar, quebrando talvez o decoro de um rigor muito científico, mas muito ineficaz em casos como este. Vejamos. Há três conjuntos de dois versos, que são os três momentos do pulso. Exatamente os tercetos se sobrepõem, ou se misturam, porque a onda se dá ao longo de mais de um deles. Crispa-se o espírito do ouvinte, junto com o do poeta, no momento em que se eleva frente ao novo horizonte (dois primeiros versos). No jogo da crispação, o leitor se sente abaixar quando tudo parece já vetho e conhecido (dois versos seguintes, o último do primeiro terceto e o pri-

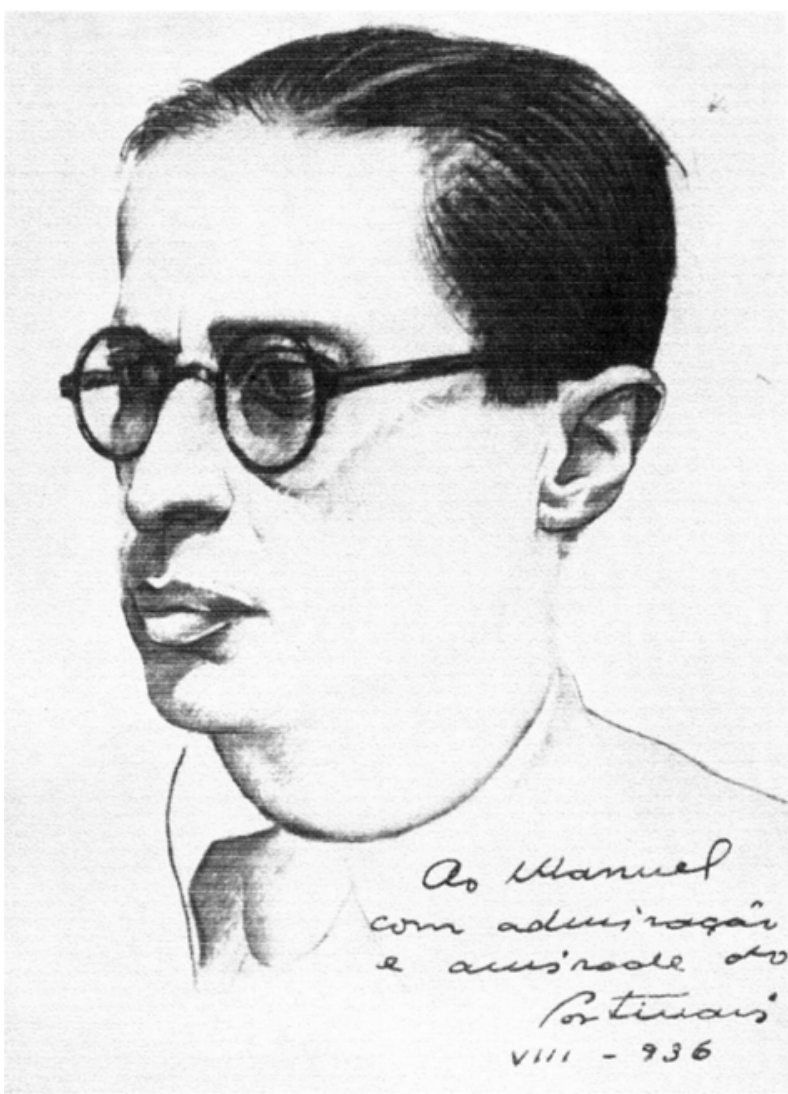

Desenho a carvão por Portinari (1936) meiro do segundo). Enfim, a onda se renova (volta, volta, "Volto", "Volto"...) com o banho na madrugada, que repõe o dia e a luz perdidos (dois últimos versos).

No movimento todo, em conjunto, uma onda formou-se. Mas o segundo terceto não se encerra no círculo, porque na verdade não se fecha sobre si mesmo, anunciando talvez uma segunda parte do poema, ou permitindo que se o parta em dois, marcando dois momentos distintos. Isto supondo, é claro, que se possa partir o poema sem violentá-lo...

Anuncia-se, ao fim do sexto verso, um momento de pausa, quando o único movimento possível será, paradoxalmente, o da partida definitiva, rumo ao não-movimento absoluto. O segredo para esta inflexão no poema talvez repouse mesmo sob seu sexto verso:

Volto a banhar meus olhos no mênstruo incruento das madrugadas.

Vinda a aurora, vem também a experiência de reviver o espetáculo da madrugada. Tudo repleto de sentido aqui: as madrugadas, o mênstruo incruento... Uma imagem forte, chocante à primeira vista, pode na verdade 
revelar-se quase ingênua. E mesmo o travo oferecido pelo excesso de oclusivas (mênstruo, incruento, madrugadas...) dará lugar, como se verá, a um remate dos mais amenos, no corpo do poema. Não haverá de fato, neste "mênstruo incruento", qualquer efeito mirabolante. A expressão rara, lembrando quiçá as primícias de Bandeira, não aparece para chocar os olhos ou os ouvidos e servir de adorno, mal posto, ao poema. Na pluralidade semântica dos termos se encontrará a riqueza deste verso e, talvez, uma pequena chave para compreendê-lo bem.

O "mênstruo incruento" não será apenas o fluxo sangüíneo (nãosangüíneo, no caso), ou o líquido dissolvente que ajuda na depuração das coisas. A imagem é forte, mas ganha um sentido amoroso porque tem raiz religiosa. Incruento, registra o Aurélio, é adjetivo também referente a "certo tipo de sacrifícios feitos à divindade com frutos naturais ou com produto do trabalho humano, como, por exemplo, pão e vinho". Ilumina-se assim o conteúdo de doação que se coloca, no plano sacrificial, nesta contemplação das madrugadas. O jogo imagético nos carrega (a metáfora...) a um universo todo líquido, todo fluido, que serve de ambiente acolhedor ao rito sempre renovado da entrega do poeta. Entrega à própria vida, que é ciclo e passagem, que é início sendo também fim. Não terá sido à toa, portanto, que o poeta incluiu este "incruento" no poema, substituindo-o a um "virginal" que havia antes, na versão de julho.

Nas pinturas é às vezes bastante sensível a temperatura do ambiente retratado. Aqui neste quadro, pintado neste verso, haverá também uma temperatura própria. $\mathrm{O}$ ambiente parece tépido. A serenidade que vai se instalando na alma toda pura (virginal afinal), como afecção da própria natureza, do mundo físico que nos rodeia e nos engloba, transmite-se num ambiente morno, quase frio, em que são contidos os extremos do calor e a desmedida fixidez do mundo enregelado pelo frio. O sacrifício virá, mas sem excessos. Os versos vêm, mas vêm calmos, serenos, como que naturalmente...

De qualquer modo, neste mundo tépido em que mergulha o poeta, há o momento marcante do enfrentamento da vida. A aurora é retomada, no instante mesmo em que o sacrifício de todos os dias aponta a fugacidade da existência, inscrita num ciclo natural, como as ondas aliás. A volta do conhecimento da aurora ou das madrugadas confirma o ciclo todo, que é o ciclo da vida e da morte. A "madrugada" não está apenas no instante de contemplação à janela. Madurare é “'amadurecer'; 'apressar, acelerar', donde "levantar-se cedo"”. Nas madrugadas se envelhece. Nelas, cabe o sacrifício diuturno da carne e do sangue. O poeta amadurecia. Preparava-se para a morte, como em toda a vida. 
Há então o "segundo" momento do poema. Lançados que fomos no ritmo ondulante da vida, do passado e do futuro evocados, há agora o necessário enfrentamento do seu fim, do sentido que se oculta na morte. É a indesejada das gentes que espreita. Impossível ler Lua Nova sem voltar os olhos a Consoada, poema imediatamente anterior em Opus 10...

É da paisagem da janela de seu novo apartamento que Manuel Bandeira retira o mote da partida definitiva:

Todas as manhãs o aeroporto em frente me dá lições de partir.

O prosaico dos aviões partindo transforma-se na lição de vida e de morte. Partem, e não se sabe se voltarão. Há que aprender com o aeroporto:

Hei de aprender com ele

A partir de uma vez

- Sem medo,

Sem remorso,

Sem saudade.

As lições de partir: sem medo, sem remorso, sem saudade. Estoicamente. A espera da partida definitiva, pressentida e vivida a cada madrugada, reforçada pelo rito sacrificial que é a contemplação da própria vida, é acompanhada da lição da tranqüilidade com que partem os aviões, indefectivelmente, “todas as manhãs”.

As paixões e os afetos não são apenas domados, porque isto levaria ao amargor mais completo. Paixões e afetos são quase extintos, no caminho da morte. Epicteto conta, sobre Agripino, que certo dia lhe fora anunciado seu julgamento pelo Senado. Ao que ele teria respondido: "A la bonne heure; mais voici la cinquième heure, sortons et faisons nos exercices". Durante os exercícios, alguém lhe diz: "Tu as été condamné." Ele responde: "A l'exil ou à la mort?" Ao exílio, dizem-lhe. "Et mes biens?" "Ils ne sont pas confisqués", respondem-lhe. Ao que resolve Agripino: "Partons donc et allons dîner à Aricie.” Epicteto considera Agripino um sábio, porque indiferente a tudo aquilo que não depende dele:

C'est qu'il a fait les méditations qu'il fallait faire; il s'est préparé à ne trouver ni obstacle à sa volonté ni risque de tomber dans ce qu'il veut éviter. Il me faut mourir: si c'est à l'instant, je meurs; si c'est un peu plus tard, je dîne, puisque c'est l'heure; après, je mourrai. Comment? Comme il convient à un homme qui rend ce qui n'est pas à lui (12). 
Epicteto fala de indiferença. Mas não se tratará, porventura, de desdém pelo mundo. Será bem mais a postura virtuosa de não se ater ao turbulento do universo mundano, ou de conviver serenamente com ele, tendo sempre como horizonte a morte, quando se calam definitivamente as paixões e os afetos e se reencontra a paz perpétua, que o mundo parece negar todos os dias.

É freqüentemente reforçada pela crítica, e por ele mesmo, a importância da morte iminente na arte poética de Manuel Bandeira. Não há aparentemente como duvidar disso. A morte é tema constante, tratado com graça, com a virtude serena de quem não a teme, ou que, ainda podendo temê-la, não deixará nunca de manter "cada coisa em seu lugar", esperando-a naturalmente, não importa se para antes ou depois do jantar.

A atitude serena, longe de representar sobranceria, pode significar humildade. Fruto, porém, de um árduo treinamento, realizado na convivência com a morte, em seu significado pleno, sempre no limite da falta absoluta, seja dos familiares, dos amigos, ou de si mesmo. Uma vez mais, a ausência absoluta se coloca no horizonte do homem, adensando o significado da experiência e aprofundando o sentido da vida. Tudo fruto de experiência, da vivência significante que o poeta procura. Fruto da biografia do homem vincado pela doença. Mas tudo temperado por um estoicismo de fundo, porque se é virtuoso quando se espera serenamente a morte, aprendendo as lições de partir, todos os dias.

É uma busca, de qualquer forma. Busca da morte, mas também daquelas lições que encerra a vida. Há de aprender, o poeta. Há de partir sem medo, sem remorso ou saudade. A absoluta paz que advém da falta de afetos, ou do domínio sobre eles, é reforçada no poema, novamente, pelo movimento sonoro: a anáfora marca um continuum de recusas ( "...Sem medo, /Sem remorso, / Sem saudade.”). Um domínio sobre si mesmo, em busca de uma harmonia do ser, a se reencontrar no conjunto da natureza, de que ele faz parte e à qual retornará, ainda como ser.

Mas arrisquemos um pouco mais na análise. Imaginemos o que afinal se encerra na "lua nova" do poeta. Pois ele a quer, ele a deseja. Antes porém, impõe-se-me um excurso. Se arrisco na análise, ponho-me desarmado, baixando a guarda para escutar o poema. A tentativa de interpretação é talvez mais difícil aqui, quando nos aproximamos do fim, porque é então que se busca a solução da compreensão. Até aqui, apenas uns fios soltos foram lançados, quase sem ordem, sobre o poema. Chega a hora de puxálos e de verificar qual o desenho da trama que formaram. Que sentido terá o poema? Que me dirá no íntimo? Terei falhado na interpretação? Terei 
ouvido o poeta realmente? Seria eu capaz de tornar presentes os sentidos que subjazem no texto? Encontrarei a prosódia adequada, para fazer valer a leitura? Serei capaz de captar algo minimamente próximo àquilo que passou pela alma do poeta?

Eis o exercício crítico: crisis é critério, julgamento. A crítica é a própria crise estampada no não encontro, na procura incessante, no quase abandono de si, sem que se encontre completamente o outro. A viagem de busca pode revelar-se, contudo, proveitosa. Se parto e não encontro o outro, tampouco encontrarei a mim mesmo, na torna-viagem. Ao menos não me encontrarei da mesma forma como iniciei. Encontro-me outro, eu mesmo.

É sempre a procura de algo novo que se põe no horizonte. Novo, mas que dificilmente se deixa apreender, porque sequer é possível determinar o sentido da busca individual; será este o desconcerto moderno. Manuel Bandeira, muito ternamente, muito modernamente, procura a lua nova. Antes, porém, recusa a lua cheia. Não é ela que ele aguarda:

Não pensem que estou aguardando a lua cheia

- Esse sol da demência

Vaga e noctâmbula.

O que en mais quero,

$O$ de que preciso

É de lua nova.

A demência se afigura terrível, estampada na imagem da lua cheia, quase sol, brilhante e cegante. Toda excessiva, a lua dos três primeiros versos deste sexteto é a própria loucura que espreita a vida. Excesso de luz e de movimento, o astro vagamundo é ali a encarnação do sentido da incontinência absoluta, do homem ébrio de paixão, arrebatado e extático diante do maravilhoso espetáculo que se lhe apresenta, na vida ou na simples paisagem noturna.

Esta paisagem, porém, não traz consigo a calma costumeira de uma noite enluarada, antes implanta no poema um cenário de quase pesadelo, como se este falso sol carregasse consigo a "verdade tórrida" do páthos humano, que o poeta vai recusar, estoicamente mais uma vez. O quadro assim pintado, nos três versos, pode evocar o homem alucinado, paradoxalmente privado da luz pelo seu excesso. A lua cheia, como o sol, não se olha fixamente. Engana-se quem pensa que o poeta a aguarda, embevecido pelo fulgor e pela certeza da luz mais completa. Bem outro é seu movimento. 
Ao mundo ebuliente das paixões, ele vai contrapor, nos três versos seguintes, um mundo que não chega a precisar, ou a descrever, mas que é pura intenção, pura busca de um nexo de vida, ainda frágil, mas fundamente significante.

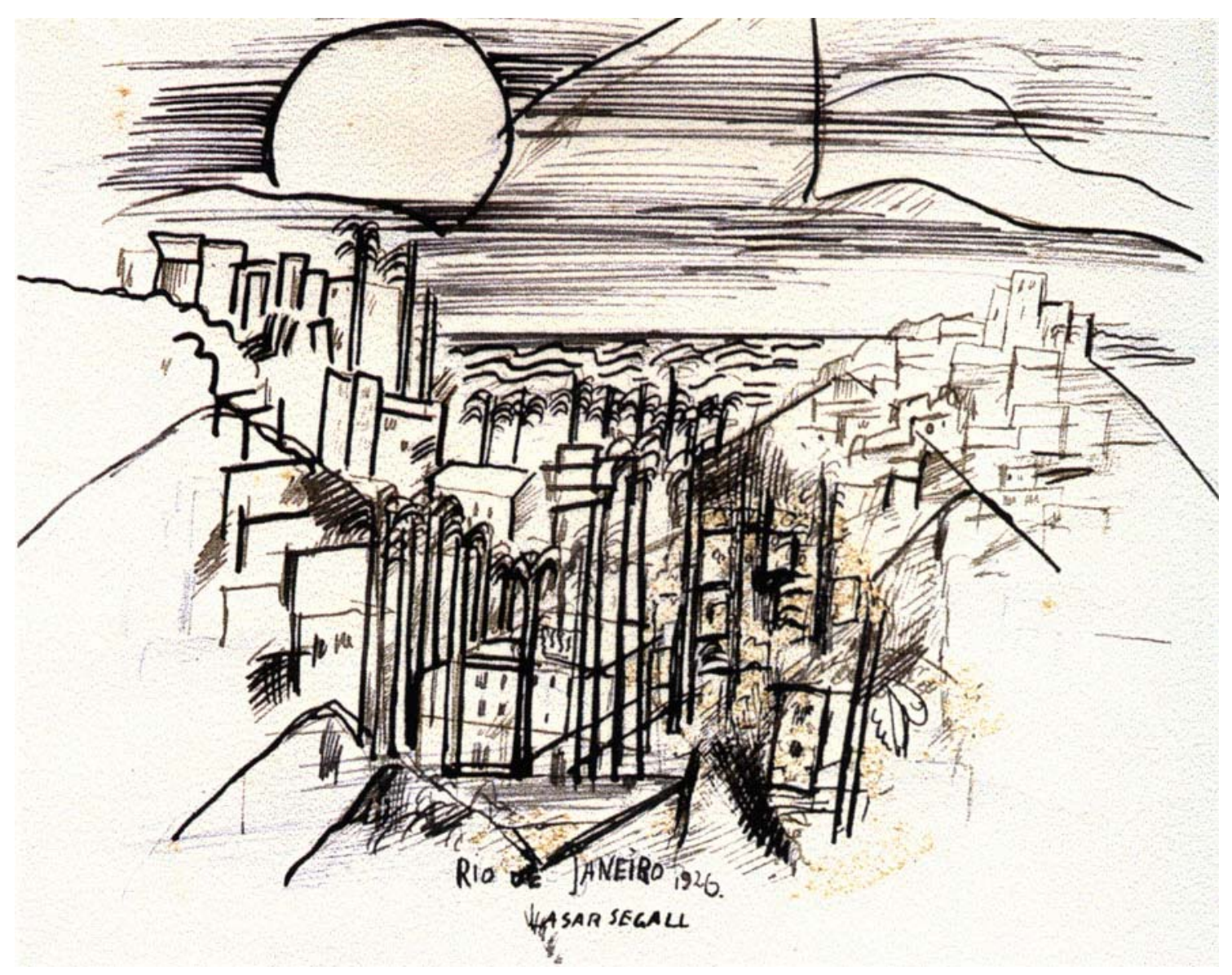

Paisagem do Rio de Janeiro. Lasar Segall, tinta preta a pena sobre papel, 1926.

O poeta parece recolher-se, mas não à procura da morte tão-somente. Os três últimos versos de Lua Nova afetam uma singular calma no espírito de quem lê. Bem verdade que um frêmito de desejo parece percorrer o corpo de quem escreveu e com ele fremimos.

Porém, é um desejo a um só tempo contido e humilde. Na chave já consagrada pela crítica, o poeta busca sempre os mais humildes objetos (13). Recusa a lua cheia e procura a lua nova, matéria fina e frágil como ele. Mas há ainda o desejo, temperado porém pela serenidade e pela calma de 
quem espera resignado a partida definitiva, de quem se sabe delével e não se ilude sequer com a luz mais promissora.

Se os três primeiros versos do sexteto apontavam o aturdimento do homem pelo excesso da vida e pelas promessas vãs da luz, os três versos finais deixam-se habitar pelo seu desejo de recolhimento, como se o fragmento dos primeiros filósofos do Pórtico se fizesse ouvir, quase em sussurro, carregado de sábia certeza: “...a apatia é do sábio e todas as paixões do insensato..."(14).

No jogo das pathes, o poeta optou pela apatia (apathe), que aqui significa bem mais o recolhimento que a falta de ânimo. O espírito, afinal, continua ativo, mesmo ao fim de um poema que tem por horizonte a vida fugidia, no limite da morte, da ausência absoluta, da cessação definitiva de todo o movimento e de toda a vontade.

Não é à toa que o desejo derradeiro seja o da lua nova. Com ela, o poeta diz por fim que aceita a morte, porém mantendo acesa a vida, em sua efetividade. A lua nova vem como renovação serena do sacrifício diário, como reencontro do ciclo da vida e da morte. Como ela, o poeta mergulha no fluxo incessante que não há como estancar, mas que nem por isso podese recusar.

\section{Conclusão...?}

Ao cabo do curso seguido até aqui, eis que a poesia se revela em sua dupla entrega. Em primeiro lugar, entrega do leitor à superfície do texto, às palavras do poeta, para nelas sentir o pulsar de correntes mais fundas, que o liguem porventura a uma outra alma. Única forma talvez de vencer aquela assertiva de Bandeira: as almas são incomunicáveis... Mas não se trata mesmo, como se tentou ver, de encontrar uma única solução amorosa, em que as almas se confundam e se componham. Afinal, seguimos descobrindo na poesia do outro também aquilo que nós mesmos somos, não apenas aquilo que o outro foi ou é. A experiência do outro ganha sentido no que tem de universal, no que nos atinge, a nós mesmos. Não havendo composição, haverá tão somente compreensão.

Mas há ainda outra entrega, a entrega ao mundo: um entregar-se iniludível, que é do poeta e é daquele que se arrisca na aventura da leitura. Ao fazê-lo, o leitor deve esperar a surpresa e o desconhecido, o advento constante, imanente e infinito, guardado no seio da poesia. Deve mesmo esperar que a poesia não seja de todo edificante, porque trava com o mundo uma relação de vida e de morte, nem sempre concorde, nem sempre com- 
pletamente harmoniosa. Já se falou mesmo do caráter detonador da poesia. Poesia-recusa, poesia-negação, poesia-resistência (15).

No fecho da República de Platão, referindo-se ao poeta-imitador, Sócrates sugere a Glauco que se o expulse da Cidade. Incapaz de atingir o Ser, o poeta se contenta afinal com o jogo das aparências, imitando aquilo que já é mera imitação. No início e no fim de tudo, pairam as idéias, absolutas, imutáveis, sempre iguais a si mesmas. Os homens comuns, ignorantes, contentam-se com um jogo de sombras. E o poeta se compraz em criar duplas sombras: sombras das sombras. Imagens das imagens. $\mathrm{O}$ discurso sibilino de Sócrates encontra no poeta um inimigo, que se recusa a ver e a aceitar o que é. Um tolo, que fecha as vistas ao mundo límpido e claro da verdade. Verdade do Filósofo. Verdade da Razão. Verdade da Cidade.

Mas os gregos amiúde filosofavam como poetas. Ou poetavam como filósofos. É curioso - no mínimo curioso - que a graça poética desponte ao fim da República, em meio à fala manhosa de Sócrates, esta alma clarividente e segura que profere suas sentenças diante de um Glauco quase boçal, porque em tudo concorde e servil. A dialética bem costurada e irretorquível cede espaço, num breve e derradeiro instante, no fim do décimo livro, à imagem transcendente da alegoria poética: no sonho de Er, o grande fuso da Vida repousa no colo da Necessidade e as Moiras Láquesis, Cloto e Átropo seguem girando as oito rocas do céu, entoando o presente, o passado e o futuro.

As almas se põem diante do espetáculo do imenso e complexo fuso e escolhem seus próprios destinos, tramados então pelas três Moiras, enquanto giram as rocas em sentidos diversos. Antes que as almas despertem para a vida, há a passagem pela planície do Lete, tórrida e árida. Entre o tempo da morte e o tempo do renascimento para a vida, restam mil anos (16).

Sócrates fala do sonho de Er com uma firmeza próxima àquela certeza divinatória do profeta. Sugere a Glauco a prática da justiça e da sabedoria, para que a própria vida e os mil anos seguintes à morte sejam felizes. Serão estes os mil anos da esperança, dos apocalipses e da poesia subversiva de todo o tempo? Não talvez. Ao menos não no discurso racional de Sócrates. Nele, a poesia perverte, porque teima em ater-se ao mundo sombrio dos homens comuns. Já a ordem da República reclama o claro concerto das almas, numa regulação sábia, emanada da Filosofia dos Governantes.

Mas a poesia recusa a ordem e a regulação, desordenando e desregulando o mundo, experimentando-o cotidianamente como novidade, como total perversão do que é, apontando o que será ou o que já foi. Reexperien- 
ciando-o. Ao menos isto parece possível no registro da poesia-resistência. Em Manuel Bandeira, o que será aparece como uma projeção utópica que retoma o passado imaculado, do menino ainda não doente, a quem não faltaram nem faltarão jamais o pai, a mãe ou a irmã. A graça toda poderá residir no simples grito infantil, no ritornello das cantigas e dos rondós, num zinir de cigarra, num coaxo de sapo e sempre, quase sempre, na musicalidade pueril dos sons de seus versos. Aí a subversão. O pátio cotidiano pode guardar um repentino guincho de sagüim, que corta rápido o próprio mundo, revelando-o por um flanco inesperado, desconcertando o leitor. A vida pulsa nos detalhes trazidos à tona pela poesia. Nós outros, os leitores, captamo-la como sinal modulado na alma do poeta, e a reverberamos em nossa própria alma e no corpo, segundo os registros que podemos compreender, apreendendo-a como vivência, revivendo-a como experiência.

O exercício que daí advém é fortíssimo, sobretudo porque mistura os tempos, sem confundi-los porém. Tempos do poeta e do leitor. Passado, presente e futuro, de um e de outro. Como se o desenho da infância perdida, da saúde que se esvai, do pai e da mãe ausentes, evocasse outros tantos tempos, sobrepondo à trama do destino pessoal do poeta a trama de meu próprio destino, eu-leitor. O gigantesco fuso trabalha, e as almas passam por sob o arco da Necessidade.

Sócrates, ao elogiar a virtude e a sabedoria, ao erguer os muros imaginários da Cidade, e mesmo ao expulsar de lá o poeta, precisou enxergar, ainda que por um breve instante, o mundo onírico de Er. O campo mitopoético permitiu-lhes, a ele e a seu fiel interlocutor, vislumbrar um mundo que, afinal, não era aquele em que viviam. A República de Platão não seria o mundo sofisticamente governado. A felicidade pulsava, mas não somente na utopia certa da Cidade ideal. A felicidade cintilava como possibilidade, entrevista apenas, a guardar-se no horizonte de uma viagem longuíssima, pelo céu ou pelo inferno. O sonho do homem descortinava os mil anos que virão. A aventura da alma, fosse ainda regrada e obediente, valia-se dos recursos poéticos para projetar-se. Sócrates recusou a poesia. Mas precisou dela.

Notas

1 Manuel Bandeira. Cantadores do Nordeste. In: Poesia completa e prosa. Rio de Janeiro, Nova Aguilar, 1996, p.342. (Louvações.)

2 Carta de Manuel Bandeira a Sergio Buarque de Holanda. Fundo Privado Sergio Buarque de Holanda, Siarq/Unicamp. 
3 Justifico o aparente pleonasmo: recentemente, um professor de Português ensinou que "engraçado, no vernáculo clássico, quer dizer cheio de graça, ao mesmo tempo gracioso e gratuito". Explicava-me então uma frase do místico Manuel Bernardes, que chamara a Deus "engraçado", extático diante da beleza da paisagem do seu Portugal. Aqui também, no caso de Bandeira, haverá graça. A gratuidade e graciosidade de suas palavras fazem realmente com que um "místico ateu" como ele possa revelar-se, ao fim... engraçado! O tema da graça está bem estampado no Itinerário de Pasárgada, quando o poeta se refere à sua incapacidade de seguir Valéry, na busca da máxima consciência possível no trabalho de criação poética. A partir de Libertinagem, diria ele, havia se resignado "à condição de poeta quando Deus é servido"...

4 Veja-se o belo ensaio de Laymert Garcia dos Santos, intitulado "A experiência da agonia”. In: Tempo de ensaio. São Paulo, Cia. das Letras, 1989.

5 Inspiro-me aqui largamente nas reflexões de Alfredo Bosi sobre "O som no signo". In: O ser e o tempo da poesia. São Paulo, Cultrix, 1993.

6 Para uma interessante interpretação da inspiração diltheyana na crítica literária, consulte-se a dissertação de Maria do Carmo Malheiros Waizbort. Um diálogo crítico: Otto Maria Carpeaux e as "ciências do espirito". São Paulo, 1992. Dissertação (mestrado). Departamento de Letras Clássicas e Vernáculas da Faculdade de Filosofia, Letras e Ciências Humanas da Universidade de São Paulo.

7 Wilhelm Dillthey. Goethe y la fantasía poética. In: Vida y poesía. Trad. Wenceslao Roces. México, Fondo de Cultura, 1978, p.128 (título original: Das Erlebnis und die Dichtung).

8 Id., ibid., p.129.

9 Id., ibid., p.140.

10 "Filologia ativa. Leitura na qual a linguagem toma corpo através da sintonia do corpo que ouve com o corpo que enuncia. Reencontrar o texto primitivo do homem: retorno da língua à metáfora intuitiva, ao natural da linguagem figurada. 'De tudo o que se escreve, só aprecio o que se escreve com o próprio sangue. Escreve com o sangue e descobrirás que o sangue é espírito. Não é fácil ouvir o sangue dos outros: odiosos são, para mim, os ociosos que lêem'”. Laymert Garcia dos Santos. "A experiência da agonia", op. cit., p.34. A citação é do Zaratustra de Nietzsche, em "Do ler e do escrever".

11 A propósito do improviso ou da construção cuidadosa que pode caracterizar o trabalho poético, fica claro aqui o intenso labor com as palavras, ao longo do tempo. Este não é, evidentemente, um poema que tenha surgido no "correr da pena", como vários outros, segundo noticia o poeta. $\mathrm{O}$ poema publicado, datado de agosto de 1953, é um pouco diferente do poema enviado em julho a Sergio Buarque de Holanda, numa versão que não continha ainda o terceiro verso ("Meu quarto, de novo a cavaleiro da entrada da barra"). Sem a presença 
desse verso, perde-se muito do movimento cíclico da estrofe, tanto no aspecto semântico quanto rítmico. Os dois pontos, enfatizando a anunciação e criando a expectativa da novidade, fortalecem aquele movimento à medida que o passo seguinte, de retorno ao passado (conforme o terceiro verso), é exatamente o contrário do que se esperava (a novidade), criando um choque na expectativa e reforçando, com a surpresa e o inesperado do retorno, a importância do terceiro verso, marcando ademais a presença forte do círculo e do tempo no poema. $\mathrm{Na}$ versão de julho, havia apenas um ponto final onde mais tarde se incluiriam os dois pontos (Meu novo quarto / Virado para o nascente.)

12 Épictète. Indifférence du sage à ce qui ne dépend pas de lui. (Entretiens, I). In: Les stoïciens. Trad. Émile Bréhier. Paris, Gallimard, 1997, v. II, p. 810-811.

13 Refiro-me por exemplo a Davi Arrigucci Jr. Veja-se, a propósito, o ensaio "Paixão recolhida". In: Humildade, paixão e morte: a poesia de Manuel Bandeira. São Paulo, Cia. Das Letras, 1990.

14 Apud Rachel Gazolla de Andrade. O ofício do filósofo (um estudo sobre o estoicismo antigo). São Paulo, 1983. Dissertação (mestrado). Departamento de Filosofia da Faculdade de Filosofia, Letras e Ciências Humanas da USP.

15 Inspiro-me novamente num conhecido ensaio de Alfredo Bosi, intitulado "Poesia resistência". In: O ser e o tempo da poesia,. op.cit.

16 Platão. A República. Trad. Enrico Corvisieri. São Paulo, Nova Cultural, 1997.

RESUMO - NESTE ARTIGO procuro analisar criticamente um poema de Manuel Bandeira, intitulado Lua Nova, composto no Rio de Janeiro em 1953. Lendo os versos à luz de algumas reflexões de Dilthey, busco neles a expressão das vivências do poeta, tentando assim compreender, através de Lua Nova, sua constante recusa de todo o excesso e sua serena aceitação do ritmo da vida, que contém como fim inevitável e fundamente significativo a própria morte.

ABSTRACT - THIS PAPER is an attempt at analysing a poem by Manuel Bandeira, called Lua Nova, composed in 1953 in Rio de Janeiro. Reading the verses in the light of some Dilthey's reflections, I look for the expression of the poet's experiences, then trying to understand, through Lua Nova, his constant refusal of all excess and his serene acceptance of life's rhythm, which contains as an inevitable and deeply significant end death itself.

Pedro Meira Monteiro é mestre em Sociologia pela Unicamp, doutorando em Teoria Literária pela mesma Universidade e atualmente bolsista da Fapesp. Autor de A Queda do aventureiro: aventura, cordialidade e os novos tempos em Raizes do Brasil. Campinas, Editora da Unicamp, 1999 (no prelo). O autor agradece a Alcides Villaça e a Luiz Dantas a interlocução sugestiva e fecunda para a consecução deste artigo. 